\title{
KATABOLISME RUANG DAN UTILISASI KOMUNITAS SEBAGAI STRATEGI KEBERTAHANAN PESANTREN
}

\section{Catabolism of Space and utilization of community as A Survival Strategy of Pesantren}

\author{
Yudha Heryawan Asnawi*), Endriatmo Soetarto, Didin S. Damanhuri, dan Satyawan Sunito \\ Departemen Sains Komunikasi dan Pengembangan Masyarakat, Fakultas Ekologi Manusia IPB. \\ *) E-mail: yudhaherryasanawi@yahoo.com.
}

\begin{abstract}
Through out in history of pesantren is not a stagnant entity. Pesantren has undergone various linkages from early history to this present. Initially pesantren is an institution with simple spaces which are turned into an institution with the complexity of space. Consider from the physical structure, initially, pesantren has three buildingsor facilities that are the mosque, majlis-taklim and house of Kyai. The third building is a building for education space. Along with the development in the peripheral of pesantren environment currently emerging business space.This paper discusses the development of pesantren space, using the conditions of pesantren in the late 19th century to the present. The discussion using an arrangement of the history and growth of pesantren space by taking the case at Sidogiri Pesantren, Pasuruan, East Java.This paper uses a constructivist approach that is hermeneutic and dialectical where the individual social construction can acquire and known through interactions between researcher and actors of research. In addition, this study also emphasizes empathy and dialectic interaction between researchers and informants in order to reconstruct the social reality under study with qualitative methods. The survey results of the research revealed that the emerging new spaces at the pesantren that is the internal business space and external business collaboration space that complements the mosque, majlis taklim and house of Kyai who had been already there. The new of economy spaces (business spaces), and with the community formed can be a tool for survival strategy of Pesantren. Even to this day pesantren persist with the principles of Islamic, but remains on the threat of consequences: without the moral control of religion, and the charisma of kyai, Pesantren can be a greedy capitalist machine as generally.
\end{abstract}

Keywords: transformation, economic space, pesantren

\begin{abstract}
ABSTRAK
Sepanjang sejarahnya pesantren bukanlah entitas stagnan. Pesantren telah mengalami berbagai kebersinggungan dari awal sejarahnya hingga saat ini. Pesantren yang pada awalnya adalah sebuah lembaga dengan ruang-ruang yang sederhana kini berubah menjadi lembaga dengan kompleksitas ruang. Dilihat dari struktur fisik, pada awalnya pesantren mempunyai tiga bangunan atau fasilitas yaitu masjid, majlis taklim dan rumah Kyai. Ketiga bangunan tersebut merupakan bangunan untuk ruang pendidikan. Seiring dengan perkembangan, saat ini di lingkungan pesantren muncul ruang-ruang bisnis. Tulisan ini membahas mengenai perkembangan ruang pesantren, menggunakan kondisi pesantren pada akhir abad 19 hingga saat ini. Pembahasan menggunakan Setting sejarah dan pertumbuhan ruang pesantren dengan mengambil contoh kasus di Pondok Pesantren Sidogiri, Pasuruan Jawa Timur. Tulisan ini menggunakan pendekatan konstruktivis yang bersifat hermeunetikal dan dialektikal dimana konstruksi sosial individu dapat diperoleh dan diketahui melalui interaksi antara peneliti dan tineliti. Di samping itu, penelitian ini juga menekankan empati dan interaksi dialektif antara peneliti dan informan dalam rangka merekonstruksi realitas sosial yang diteliti dengan metode kualitatif. Dari hasil penelitian diketahui bahwa muncul ruang-ruang baru di pesantren yaitu ruang usaha internal dan ruang kolaborasi bisnis eksternal yang melengkapi ruang masjid, majlis taklim dan rumah kyai yg selama ini sudah ada.Ruang-ruang ekonomi baru (ruang bisnis) dan pembentukan komunitas telah menjadi sebuah alat dan strategi kebertahanan pesantren. Sekalipun sampai saat ini pesantren bertahan dengan prinsip keislaman, namun tetap pada ancaman konsekuensi: ketika terjadi pelemahan pada kontrol moral dari pengajaran agama, dan kharisma kyai yang dimilikinya, maka pesantren dapat menjadi mesin kapitalisme yang serakah sebagaimana umumnya.
\end{abstract}

Kata kunci: transformasi, ruang ekonomi pesantren

\section{PENDAHULUAN}

Penelitian dan kajian masalah sosial ekonomi di pedesaan, lebih banyak difokuskan pada masalah petani dan pertanian, yaitu petani sebagai aktor dan pertanian sebagai institusi sosial ekonomi yang menggerakannya, padahal desa sebagai sebuah lingkungan sosial memiliki kompleksitas lebih dari sekedar masalah hubungan petani dan pertanian. Sejarah terbentuknya desa terutama di desa-desa pulau Jawa juga terbentuk oleh tokoh agama yang dalam tradisi Islam di pulau Jawa disebut sebagai kyai. kehadiran kyai di desa-desa membentuk kelompok belajar, yang para pesertanya disebut dengan istilah santri. Dari sanalah kemudian muncul istilah pesantren. Menurut Ashrohah(2004) kyai yang mendirikan pesantren, diberikan hak-hak khusus oleh kerajaan berupa tanah perdikan, yaitu tanah yang tidak dipungut pajak oleh kerajaan. Bruinessen (2012) mencatat ada 244 tanah perdikan yang secara eksplisit dipergunakan untuk pesantren dan ada lima desa pesantren didirikan pada masa kesultanan Yogyakarta-Surakarta di abad 18.

Sampai pada abad 19, pesantren merupakan satu-satunya lembaga pendidikan untuk masyarakat pribumi, terutama yang ada di desa-desa. Pesantren terutama di desa-desa di Jawa merupakan kontributor terbesar untuk menciptakan masyarakat literacy. Baru pada paruh kedua abad ke-19, tepatnya pada tahun 1854 pemerintah kolonial Belanda menyelenggarakan pendidikan bagi kaum pribumi dengan tujuan untuk memajukan kepentingan-kepentingan ekonomi 
kaum Liberal di negeri jajahan dan keperluan perluasan birokrasi pemerintahan kolonial(Latif. 2012). Pemerintah kolonial Belanda menganggap pendidikan merupakan sesuatu alat menuju kemajuan dan sarana untuk memperbaiki kesejahteraan kaum Pribumi dalam kerangka peradaban yang terinspirasi Barat (Van niel: 1970). Dengan hadirnya sistem pendidikan kolonial pesantren menghadapi pesaing di lingkup masyarakat pedesaan, bukan hanya pada aspek pendidikan, tetapi lebih luas pada aspek sosial, politik dan ekonomi.

Pada masa Kolonial, sistem pendidikan dihadapkan pada realita-realita pragmatik. Bagi kolonialisme, penyelenggaraan pendidikan mengandung sebuah dilema. Di satu sisi, penting untuk mendukung ekonomi-politik, industrialisasi dan birokratisasi. Namun di sisi lain, pendidikan mengandung ancaman mengenai superioritas kolonial. Karenanya dilema semacam itu dipecahkan dengan membangun pendidikan yang didasarkan pada prinsip segregasi etnik dan hirarki status. Dengan dasar segregasi dan pembedaan status ini, sifat dari kebijakan-kebijakan awal dalam pendidikan di Hindia- Belanda adalah anti-asimilasi, elitis dan dualistik. Sedangkan bagi pesantren usaha pendidikan adalah untuk memainkan sebuah peran kunci dalam membangun identitas bagi masyarakat Islam melawan hegemoni Kolonial.

Kebijakan pendidikan yang segregatif dari pemerintah kolonial menimbulkan Vivalisme masyarakat Islam, ditandai dengan semakin banyaknya pesantren-pesantren tumbuh di pedesaan Jawa. Dari sanalah hubungan negara dengan pesantren memasuki aras politik. Pesantren dianggap sebagai sebuah ancaman politik oleh karenannya upaya-upaya melemahkan pesantren mulai dilakukan. Pemerintah kolonial memberikan perhatian yang lebih serius, berbagai langkah diambil untuk mengontrol perkembangan Islam dan pesantren pada khususnya. Pada tahun 1905, pihak pemerintah kolonial mengeluarkan 'Ordonansi Guru' yang mewajibkan para guru Islam mengajukan permohonan ijin mengajar kepada pihak pemerintah. Pemerintah juga mengontrol pergerakan ulama di wilayah Hindia dengan mewajibkan mereka untuk mengajukan surat jalan khusus jika kan bepergian. Sekalipun dalam teori yang dianut oleh politik ethik $\sim$ negara diharuskan mengambil posisi netral dalam urusan-urusan agama, namun dalam kenyataannya ambisi pihak kolonial untuk mengekang Islam 'yang liar' mendorong pemerintah kolonial memperkuat institusi penghulu sebagai instrumen bagi kontrol pemerintah (Steenbrink 1993). Sejak saat itu, selain ada kyai dan ulama yang independen, ada pula penghulu (kadi) yang merupakan pegawai agama dari kekuasaan yang sekuler (Benda: 1958: $15)$.

Pemerintah kolonial juga mengambil kebijakan politik lainnya yang berdampak secara sosio ekonomis terhadap pesantren yaitu dengan dikeluarkannya Surat Edaran Sekretari Gubernemen tanggal 04 Juni 1931 Nomor 1361/A termuat dalam Bijblad No. 125/3 tahun 1931 tentang Toezict van de Regering op Mohammedaansche bedehuizen Vrijdagdiensten en Wakafs. Ordonansi tersebut pada intinya memuat dua hal, pertama yang berkaitan dengan status hukum kepemilikan masjid dan yang kedua pengontrolan terhadap aktivitas masjid. Dalam hal pengaturan mengenai status hukum kepemilikan masjid, pemerintah kolonial dengan mengadopsi hukum syariat Islam, mewajibkan kyai melepaskan hak-haknya atas penguasaan masjid kepada masyarakat dalam bentuk wakaf. kedua bahwa aktivitas masjid, terutama untuk ibadah sholat jumat harus dicatatkan kepada Pelepasan masjid dari penguasaan kyai, berdampak kepada sosio politis dan ekonomi pesantren. Kyai menjadi kehilangan fasilitas tempat mengajar dan kehilangan modal sosial yang selama ini menjadi sumber pembiayaan pengelolaan pesantren.
Setelah Indonesia merdeka, pelemahan-pelemahan pada pesantren juga tetap terjadi. Pilihan berpolitik bangsa Indonesia yang mengedepankan pluralitas, menjadikan pesantren sebagai sebuah lembaga eksklusif masyarakat Islam dicurigai dapat menjadi pemicu tumbuhnya primordialisme dan ekstrimisme. Terutama pada masa pemerintahan Orde Baru, sikap kritis tokohtokoh Islam tradisional terhadap kebijakan pemerintah Orde baru, seperti UU Perkawinan, Aliran kepercayaan membuat pemerintah Orde Baru menjadi tidak nyaman. Pemerintah Orde Baru, seperti juga Pemerintah kolonial juga melakukan pelemahan terhadap ulama Islam tradisional yang kritis dengan melemahkannya pesantren. Pemerintah Orde Baru, dengan Surat Keputusan Bersama tiga dimensi, yaitu Menteri Agama, Menteri Pendidikan dan Kebudayaan dan Menteri Dalam Negeri Nomor 6 Tahun 1975, Nomor 037/4 1975 dan Nomor 36 tahun 1975 lebih memilih mengambil kebijakan nodernisasi pendidikan ke desa-desa melalui "program SD Inpres" dan formalisasi sistem pendidikan islam dalam bentuk Madrasah diniyah yang terlepas dari pesantren daripada memajukan pesantren sebagai lembaga pendidikan yang sudah ada sejak zaman dahulu, Keberadaan sekolah-sekolah negeri yang murah dan formalistik, merupakan hantaman gelombang kedua bagi pesantren di pedesaan setelah zaman politik etihik di akhir abad 19.

Dengan tekanan politik yang dialaminya, dan oleh bergesernya preferensi pendidikan masyarakat desa, alih-alih mengalami penurunan, pesantren justru tumbuh berkembang dari tahun ke tahun. Data statistik kementrian agama, Tahun 2013 menyebutkan terdapat 27.230 Pondok Pesantren yang tersebar di seluruh Indonesia. Sebanyak 78,60 \% berada di Provinsi Jawa Barat, Jawa Timur, Jawa Tengah dan Banten. Dengan rincian Jawa Barat $7.624(28,00 \%)$, Jawa Timur $6.003(22,05 \%)$, Jawa Tengah 4.276 (15,70\%), dan Banten $3.500(12,85 \%)$. Dari seluruh Pondok Pesantren yang ada, berdasarkan tipologi Pondok Pesantren, terdapat sebanyak 14.459 (53,10\%) Pondok Pesantren Salafiyah (tradisiona) dan 7.727 (28,38\%) Khalafiyah/Ashriyah (modern), serta 5.044 (18,52\%) sebagai Pondok Pesantren Kombinasi. Dari sisi pertumbuhan, pesantren tumbuh sekitar 1-1.2 persen per tahun ( Pusdatin Kementrian Agama RI. 2013).

Pertanyaaannya adalah, dengan berbagai kebijakan politik sejak zaman kolonial hingga zaman Orde baru yang tidak berpihak ,bersifat diskriminatif, dan juga oleh semakin bergesernya preferensi masyarakat desa tentang dunia pendidikan, mengapa pesantren tetap bisa bertahan. Bahkan saat ini ada beberapa pesantren menunjukkan geliat berkembang bukan hanya bergerak di bidang pendidikan tetapi juga pada bidang ekonomi. Dalam sosiologi, pesantren bisa dibaca bukan hanya sebagai instrumen pendidikan tetapi juga sebagai sebuah produksi sosial. Salah satu produksi sosial yang belum banyak dikaji adalah tentang ruang-ruang ekonomi dan konstruksi pembentukannya. Penelitian yang tajam tentang ruang-ruang ekonomi akan dapat melihat bagaimana proses perubahan terjadi, bukan semata-mata pada proses fisik tetapi pada proses transformasi peran ekonominya. Untuk memahami ruang-ruang ekonomi sebagai produk sosial, pertama-tama penting untuk ke luar dari kebiasaan dan pemahaman lama yang memahami ruang sebagai semacam realitas material yang independen (Stanley Aronowitz, :2008). Ruang dalam hal ini dilihat secara fundamental terikat pada realitas sosial. Ruang-ruang ekonomi di pesantren secara fisik dapat dikenali dan dikategorisasi serta dapat digali tata nilai yang menggerakannya.

Secara umum Penelitian ini dilakukan untuk melihat bagaimana struktur ruang-ruang ekonomi pesantren bertransformasi pada kondisi dinamis sosial politik saat ini. Sedangkan Secara khusus penelitian ini dilakukan dengan tujuan: 
1. Menganalisis dan mengkonstruksi proses pembentukan ruang-ruang ekonomi pesantren

2. Menganalisis dan mengkonstruksi dampak transformasi ruang-ruang ekonomi terhadap struktur dan nilai-nilai yang ada pada pesantren.

\section{METODE PENELITIAN}

Tulisan ini menggunakan pendekatan konstruktivis yang bersifat hermeunetikal dan dialektikal dimana konstruksi sosial individu dapat diperoleh dan diketahui melalui interaksi antara peneliti dan tineliti. Di samping itu, penelitian ini juga menekankan empati dan interaksi dialektif antara peneliti dan informan dalam rangka merekonstruksi realitas sosial yang diteliti dengan metode kualitatif.

Analisis penelitian ini menggunakan pendekatan historis dan fenomenologis. Perkembangan ruang pesantren, menggunakan setting sejarah pesantren pada akhir abad 19 hingga saat ini. Untuk analisis historis menggunakan data-data sekunder, sedangkan untuk analisis empiris contoh kasus di Pondok Pesantren Sidogiri, Pasuruan Jawa Timur.

\section{HASIL DAN PEMBAHASAN}

\section{Gambaran Umum Pondok Pesantren Sidogiri}

Pondok Pesantren Sidogiri, terletak di desa Sidogiri, Kecamatan Kraton Kabupaten Pasuruan Jawa Timur, pertama kali dibuka oleh seorang Sayyid Sulaiman dari Cirebon Jawa Barat dengan cara membabat hutan bersama salah seorang muridnya yang dibawa dari Cirebon, pada tahun Sidogiri yaitu 1718 atau 1745

Dilihat dari bidang kekhususan keilmuan. PP. sidogiri termasuk ke dalam pondok pesantren tidak bisa dikatakan sebagai pesantren dengan kekhususan pengetahuan. Ketiga bidang pengetahuan di pesantren yaitu Tasawuf, fiqih, maupun alat dipelajari di sini.Dari klasisifikasi pola pengajaran, PP. Sidogiri, satu sisi merupakan pesantren salafiyah (tradisional) yaitu mengajarkan ilmu-ilmu agama saja kepada para santri dan tetap mempertahankan bentuk aslinya dengan sematamata mengajarkan kitab yang ditulis oleh ulama abad ke 15 $\mathrm{M}$ dengan menggunakan bahasa Arab. Tetapi dari sisi sistem dan jenjang menyerupai pesantren kalafiyah (moderen) dimana dimasukannya sistem klasikal dan penjenjangan ke dalam sistem pondok. Secara umum, kegiatan pendidikan di Pondok Pesantren Sidogiri terbagi menjadi dua bagian; pendidikan madrosiyah (diniyah-klasikal), dan pendidikan ma'hadiyah (luar madrasah-non klasikal) berupa Kuliah Syariah. Pendidikan madrasah bernama Madrasah Miftahul Ulum (MMU). Program madrasah LPPS ( Luar Pondok Pesantren Sidogiri). Kurikulum yang dipakai adalah kurikulum klasik (diniyah) berupa kitab kuning yang biasa dipakai di berbagai pesantren pada umumnya.

Dari sisi sarana, saat ini di PP. Sidogiri terdapat 14 asrama santri permanen dengan jumlah kamar 276 bangsal (kamar besar semacam barak), untuk menampung santri Idadiyah:2.258(PPS), 5(LPPS).Istidadiyah: 238(PPS), 12 (LPPS), Ibtidaiyah: 1. 024 (PPS), 20(LPPS), Tsanawiyah: 1.909 (PPS) 235(LPPS), Aliyah: 720(PPS), 140 (LPPS), Kuliah Syariah: 229. Guru Tugas/Dai: 599(PPS), 31 (LPPS), Tugas kepengurusan: 14. Tugas Belajar: 27 (PPS) 1(LPPS), total keseluruhan adalah 7.462 santri. Selain terdapat asrama, dan rumah-rumah kyai di Pondok Pesantren Sidogiri juga terdapat masjid, namun sejak tahun 1960-an dikelola oleh nadhir (manajemen masjid) secara otonom.

Untuk mendukung Kemandirian finansial, Pondok Pesantren Sidogiri (PPS) didukung oleh Koperasi pondok yang sudah dirintis sejak tahun 1961, dan sudah berbadan hukum sejak 199. saat ini Koperasi pondok telah memiliki 74 cabang (toko koperasi) yang tersebar di Jawa Timur. Pada tahun 2014 omset Koperasi telah mencapai Rp.340.517.955.963,42. (Tiga ratus Empat puluh Milyar Lima ratus Tujuh belas Juta Sembilan ratus Lima puluh Lima Ribu Sembilan ratus Enam puluh tiga koma empat dua Rupiah) Per tahun dengan keuntungan mencapai Rp.9.969.306.413,38 atau mendekati angka 10 Milyar.

Disamping Koperasi Pesantren Sidogiri, yang ada ada di dalam struktur PP. Sidogiri,masih ada koperasi lain yang secara kelembagaan bukan milik pesantren dan tidak secara langsung di bawah pengelolaan pesantren, namun berafiliasi dengan pondok pesantren Sidogiri. pengurus, karyawan dan anggotanya adalah aktivis dan alumni pesantren Sidogiri. Koperasi tersebut adalah KJKS BMT MMU Sidogiri dan KJKS BMT UGT Sidogiri. Koperasi ini bergerak di bidang keuangan Baitul mal wa tamwil (BMT) sejenis koperasi simpan pinjam. Pada Rapat Anggota Tahunan (RAT) 2015, tercatat omset BMT UGT Sidogiri adalah sebesar Rp. 1.509.559.920.750 atau 1.5 Trilyun lebih. Jumlah SHU yang didistribusikan sebesar 77.231. 666.146. ( Tujuh puluh Tujuh Milyar lebih), Lima persen diantarannya adalah untuk bantuan ke PP.Sidogiri. Disamping itu BMT UGT mengeluarkan SHU untuk Jasa Pengurus dan pengawas sebesar empat persen dimana dewan pengawas tersebut diantaranya adalah kyai pengasuh dan pengelola PP.Sidogiri. Total kontribusi kedua BMT tersebut kepada pesantren Sidogiri, adalah rata-rata 7.5 milyar per tahun.

\section{Katabolisme Ruang Pesantren}

Di awal permulaan sejarahnya, pesantren lebih banyak merupakan tempat kegiatan tarekat. Kyai dan santri berkumpul melaksanakan "pengajian" ( belajar al quran) dan amalan-amalan "dzikir" atau "wirid" (formula kalimatkalimat dalam jumlah tertentu). Kegiatan pengajian atau wiridan dilakasanakan dengan methoda "suluk" yaitu tinggal bersama untuk melaksanakan ritual ibadah. Kegiatan suluk ini berpusat di masjid yang didirikan oleh sang Kyai. Pada umumnya peserta suluk adalah para lelaki dewasa, anak-anak lelaki dan Kaum wanita tidak terlibat dalam kegiatan suluk. Kegiatan suluk ini bisa berlaku berhari-hari bahkan berbulanbulan, maka dibangunlah ruangan-ruangan khusus untuk penginapan dan tempat memasak. Ruangan tersebut berada di samping kanan dan kiri masjid, sehingga menyerupai asrama. Selain asrama, di sisi masjid lainnya terdapat rumah yaitu tempat tinggal kyai dan keluarganya. Untuk selanjutnya fasilitas pesantren berkembang sesuai dengan kebutuhan dan perkembangan zaman.

Proses perkembangan ruang-ruang pesantren ini saya istilahkan sebagai proses katabolisme. Proses perkembangan ruang pesantren mirip dengan proses kimia yang terjadi pada proses katabolisme.

\section{Fase Rumah Kyai dan Masjid}

Pendirian sebuah pesantren pada abad ke 18-19 umumnya ditandai dengan pendidirian sebuah masjid oleh seorang 
tokoh agama yang disebut kyai. Untuk melengkapi Lanskap pesantren selain didirikannya sebuah masjid, juga dibangun sebuah rumah untuk kyai dan keluarganya. Fungsi Rumah kyai adalah untuk 1) tempat kumpul bersama keluarga, 3) tempat kyai memperdalam ilmunya dengan membaca kitab. 3) tempat kyai melaksanakan ibadah sholat sunnat terutama sholat malam (tahajud) 4) memanggil santri yang bersifat personal, seperti untuk sebuah teguran, permintaan tolong atau untuk penawaran menjodohkan. 5) menerima tamu umum. Dari sisi ekonomi, secara tradisi $\sim$ sebagai rumah pribadi biaya yang dikeluarkan untuk operasi rumah harus dikeluarkan oleh biaya pribadi kyai. Pengeluaran itu termasuk untuk melayani tamu yang sowan dan silaturahim

Masjid selain digunakan untuk sarana ibadah juga dijadikan sebagai tempat prendidikan( Mas'ud : 2004). Pengelolaan masjid sepenuhnya ada pada otoritas kyai (pimpinan pondok pesantren). Pada awalya, masjid dibiayai oleh dana pribadi seorang kyai. Masjid dengan seluruh dimensinya didedikasikan untuk agenda dakwah. Setelah masjid aktif sebagai sarana peribadatan, dan jamaah mulai terbentuk barulah masuk dana-dana masyarakat. Masjid berfungsi sebagai baitul mal, pada saat menjelang hari hari raya idhul fitri pemungutan dan pembagian Zakat fitrah dipusatkan di masjid. Pada prosesi pembagian zakat fitrah, kyai berfungsi sebagai amilin zakat yang berhak atas seperdelapan dari zakat fitrah yang terkumpul. Sekalipun pada kenyataannya penerimaan tersebut dikembalikan lagi oleh kyai untuk kegiatan yang ada di masjid berupa peenyediaan kitab-kitab secara gratis. Hal ini dilakukan kyai mengingat sebagian besar Kyai adalah tuan tanah di desa dan elite ekonomi yang mampu memenuhi kebutuhan rumahtangganya sendiri.

\section{Fase Masjid dan Majlis Taklim}

Pada fase berikutnya masjid mengalami pemecahan (katabolisme) menghasilkan satu ruang baru yang disebut dengan majlis. Ada dua hal yang mendorong terjadi proses katabolisme masjid. Pertama adalah adanya hukum yang memaksa dan kedua adalah adanya realitas sosial. Dalam syariat Islam (hukum Islam) sebenarnya telah diatur, bahwa sebuah tempat yang digunakan untuk sholat jumat seharusnya berdiri di atas tanah wakaf. Ketentuan syariat ini dimanfaatkan oleh hukum positif kolonial berupa ordonansi untuk menerapkan perwakafan, ,yang disisipkan pada SuratEdaran Sekretari Gubernemen tanggal 04 Juni 1931 Nomor 1361/A termuat dalam Bijblad No. 125/3 tahun 1931 tentang Toezict van de Regering op Mohammedaansche bedehuizen Vrijdagdiensten en Wakafs, sedangkan pada zaman setelah merdeka diatur melalui surat edaran jawatan urusan agama tanggal 8 oktober 1956 No. 3/D/1956. yang dikuatkan dengan Perundang-undangan (PP) 28 . Tahun 1977: tentang wakaf jawatan urusan agama agama. yang mengatur pemisahan sebagian dari harta kekayaannya yang berupa tanah milik untuk kemudian melembagakannya selama-lamanya untuk kepentingan peribadatan atau keperluan umum lainnya sesuai dengan ajaran Islam. Perwakafan memiliki konsekuensi bahwa seorang individu tidak berhak melakukan penguasaan secara personal atas harta yang ditimbulkan dari masjid baik harta bergerak maupun tetap. Harta masjid yang dapat digunakan untuk keperluan pesantren, maka dengan ketentuan yang berlaku, harta masjid hanya boleh digunakan untuk kepentingan masjid.

Sebagai realita sosial orang yang datang ke masjid terbagi menjadi dua, yang pertama adalah orang-orang yang datang ke masjid hanya untuk melaksanakan sholat saja, dan yang kedua adalah orang-orang yang ingin belajar tentang agama lebih mendalam. Kelompok kedua membutuhkan ruang untuk belajar dan berinteraksi dengan kyai secara khusus. Ruang ini membentuk suatu aturan-aturan main yang berbeda dengan aturan main yang ada di masjid pada umumnya. Pengetahuan keagamaan dan kharisma kyai sebagai guru dan kebutuhan serta rasa hormat yang tinggi dari murid( santri) memunculkan pola patron- client antara kyai dan santri. Lebih dalam aturan ini dalam dunia pesantren dikenal dengan tradisi kepatuhan. Ruang inilah yang kemudian dikenal dengan sebutan majlis taklim kyai.

Pada perkembangannya majlis taklim kyai yang sebelumnya bersifat eksklusif, berkembang mejadi dua jenis majlis taklim, yaitu majlis taklim kyai reguler dan majlis taklim kyai non reguler. Majlis taklim reguler dilakukan oleh kyai setiap hari atau mingguan, dijadwalkan secara rutin untuk santri mondok maupun santri kalong. Sedangkan majlis kyai non reguler dilakukan periode tertentu, bisa bulanan atau tahunan pada perayaan tertentu, seperti pada acara perayaan isra mikraj, Maulid Nabi dan haul. Majlis taklim non reguler disamping oleh para santri juga diikuti oleh masyarakat umum yang disebut jamaah majlis taklim. Jika pada pelaksanaan majlis reguler bersifat cost centre maka pada majlis taklim non reguler bersifat Cash in, hadirnya masyarakat umum menjadi sumber pendapatan pesantren berupa sumbangan, yang dalam istilah pesantren sering disebut sebagai ketakziman.

Pada pelaksanaannya majlis taklim secara fisik dapat dilakukan di masjid, namun bisa juga dilakukan di rumah kyai. karena masjid telah dilepaskan dari kepemilikan pribadi seorang kyai sesuai dengan ketentuan perwakafan maka masjid bukan tergolong ahliyatut tabarru' (yang dapat berderma dan memberi pinjaman). Dengan demikian sumber pembiayaan pesantren berpindah yang tadinya dari modal sosial yang berhimpun di masjid berpindah ke modal sosial yang berhimpun di majlis taklim. Modal sosial merupakan modal nafkah yang memiliki nilai tinggi pada masyarakat pedesaan ( azzahra dan Dharmawan :2015) dan hal ini pun terjadi di pesantren untuk memenuhi idealisme self sufficient ( kemandirian )dari bantuan pemerintah dan fihak yang tidak mempunyai keterkaitan emosional dengan pesantren lainnya.

\section{Fase Masjid, Majlis dan Madrasah}

Kehadiran madrasah merupakan resultanta dari dua arus kekuatan. pertama madrasah (yang selanjutnya disebut madarasah diniyah) adalah produk negara yang menginginkan ada pengaturan negara terhadap pelaksanaan pendidikan di lingkungan pesantren. SKB (Surat Keputusan Bersama) tiga dimensi, yaitu Menteri Agama, Menteri Pendidikan dan Kebudayaan dan Menteri Dalam Negeri Nomor 6 Tahun 1975, Nomor 037/4 1975 dan Nomor 36 tahun 1975 tentang peningkatan mutu pendidikan pada madrasah ditetapkan bahwa standar pendidikan madrasah sama dengan sekolah umum, Negara memiliki alasan bahwa memformalkan pendidikan di pesantren dalam rangka menyetarakannya dengan pendidikan umum lainnya. kedua, masyarakat pun mempunyai kepentingan, bahwa untuk memasuki lapangan pekerjaan dan melanjutkan pendidikan formal memerlukan ijazah, dan sistem pendidikan madarasah diniyah dapat menjawab hal tersebut.

Ruang majlis taklim tidak dapat menjawab kedua tuntutan baik yang datang dari pemerintah maupun masyarakat. Kehadiran madarasah, bukan semata-mata untuk merespon keinginan politik pemerintah maupun harapan sosial masyarakat. Namun secara ekonomi, madrasah adalah perangkat formal untuk melegalkan masuknya pembiayaan formal pendidikan ke dalam lingkungan pesantren, Jika dalam ruang majlis taklim yang non formal dianggap tabu untuk memformalkan biaya, maka dengan hadirnya madrasah sebagai lembaga pendidikan yang lebih formal dengan ukuran-ukuran pembiayaan yang jelas maka tuntutan kepada masyarakat untuk membayar 


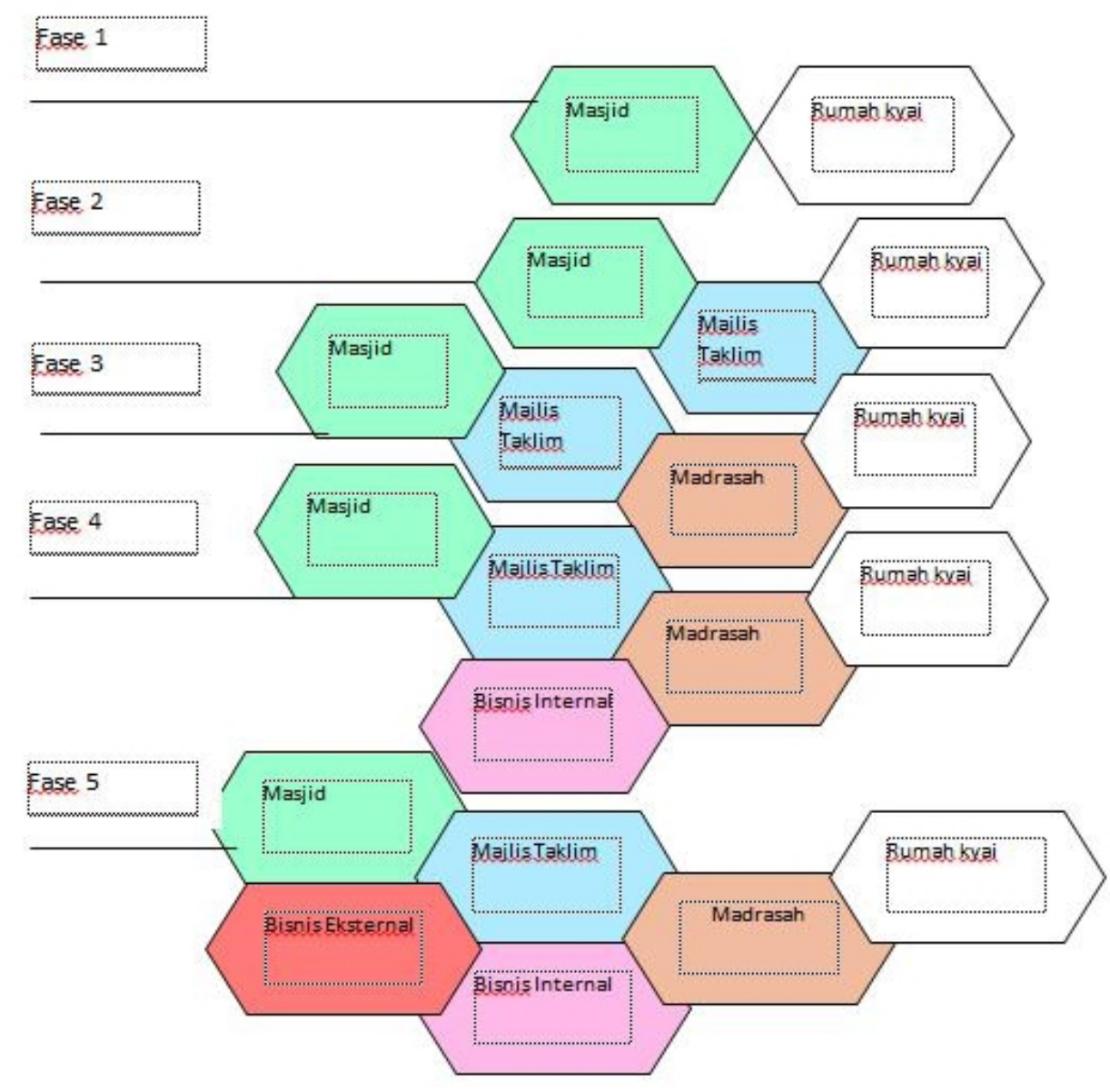

Gambar 1. Katabolisme Ruang Pesantren

pendidikan dianggap hal yang rasional. Sampai pada fase kehadiran madrasah, pesantren tetap masih dalam koridor lembaga pendidikan, yang tujuannya melahirkan alumni di bidang keagamaan dengan konsep kemandirian, self sufficient mengandalkan keterlibatan msayarakat untuk pembiayaan pendidikan yang dilakukan.

\section{Fase Hadirnya Bisnis di Pesantren}

Jika melihat latar belakang dan misi kelahirannya, pesantren didirikan dengan moralita tidak untuk mengejar surplus dan akumulasi kepemilikan pribadi. Beberapa pesantren tetap konsisten mengandalkan people driven dan self sufficient. Pesantren menjalankan roda pesantren dengan mempertahankan kemandirian, mengesampingkan bantuanbantuan pemerintah atau fihak lain yang tidak memiliki emosi pada tradisi pesantren.

Ada dua paradigma di kalangan kyai-kyai pesantren. Pertama, paradigma pesantren sebagai lembaga keulamaan. Dalam konteks ini pesantren dipahami hanya sebagai tempat pembelajaran agama untuk mencetak ulama yang nantinya diterjunkan ke tengah masyarakat. Untuk itu dipandang naif mengembangkan pesantren untuk keperluan diluar kerangka pendidikan agama dan keulamaan. Kedua, paradigma pesantren sebagai pusat pengembangan masyarakat. Paradigma ini beranggapan bahwa pesantren merupakan lembaga yang pantas dan strategis untuk pengembangan masyarakat sekitar. Pesantren dianggap mempunyai elastisitas yang tinggi dalam mensikapi setiap bentuk masyarakat yang ada. (Rimbawan :2012)
Hal ini dapat dijelaskan bahwa secara mendasar dan substantif, pesantren memiliki jaringan internal dan eksternal. Dari situ pesantren dapat mebuat berbagai aktivitas. Aktivitas internal berupa konsolidasi dan koordinasi ke dalam dengan membangun solidaritas dan komitmen. Sedang aktivitas eksternal berupa usaha-usaha pemberdayaan dan pelayanan kepada masyarakat ( Rimbawan :2012). Kedua kegiatan tersebut dapat dipandang sebagai upaya-upaya pesantren membangun kemandiriannya dalam bidang ekonomi dengan mengoptimalkan modal sosial dari dalam (internal) dan dari luar (ekternal). Modal sosial di sini diartikan sebagai bagianbagian dari organisasi sosial seperti kepercayaan, norma dan jaringan yang terkoordinasi (Putnam, Robert D. :2000), serta kepercayaan umum di dalam sebuah masyarakat. Selain itu, konsep ini juga diartikan sebagai serangkaian nilai atau norma informal yang dimiliki bersama di antara para anggota suatu kelompok yang memungkinkan terjalinnya kerjasama. (Fukuyama, :1995), Bentuk konkret dari modal sosial di lingkungan pesantren adalah munculnya ruang-ruang baru yang secara tradisi sebelumnya tidak pernah ada seperti Koperasi dan lembaga keuangan.

Keberaadaan koperasi di pesantren dapat dilihat sebagai terobosan pimpinan pondok (kyai) untuk memfasilitasi dan mengkoordinasi modal sosial internal yang dimilikinya, (seperti : kepercayaan norma dan jaringan) ke dalam bentuk usaha-usaha nyata (real business) yang melibatkan para santri dan pengelola pesantren. Sedangkan kehadiran lembaga keuangan semacan BMT (baitul mal wa tamwil) terkait dengan isu pengelolaan dana komunitas pesantren yang tidak dapat diserahkan kepada lembaga-lembaga keuangan bank-bank umum atau perusahaan asuransi jiwa 
umum yang menawarkan jasa pengelolaan keuangan karena terbentur kepada syariat Islam yang mengharamkan kedua lembaga tersebut, karena termasuk ribawi dan perjudian Dari uraian sebelumnya maka katabolisme yang terjadi pada ruang pesantren dapat digambarkan pada Gambar 1.

1) Fase pertama: Pesantren hanya terdiri dari 1)ruang Masjid dan 2) ruang Rumah kyai.

2) Fase dua: ruang Masjid mengalami pemecahan menjadi ruang Masjid dan ruang Majlis, sehingga pada fase dua ini ruang - ruang pesantren menjadi: 1)ruang Masjid, 2) ruang Majlis dan 3) ruang Rumah kyai.

3) Fase Tiga: ruang Majlis mengalami pemecahan menjadi ruang majlis dan ruang madrasah, sehingga pada fase tiga ini ruang-ruang pesantren menjadi : 1)Ruang Masjid, 2) ruang majlis, 3)ruang madrasah dan 4) ruang rumah Kyai.

4) Fase Empat: Muncul satu ruang baru diantara ruang majlis dan ruang madrasah yaitu ruang usaha internal bisa berbentuk koperasi, toko dan usaha lainnya, maka pada fase empat ini ruang-ruang pesantren menjadi: 1) ruang Masjid, 2) Ruang Majlis, 3) Ruang Madrasah, 4) ruang usaha internal, 5) ruang rumah Kyai.

5) Fase lima, muncul satu ruang baru diantara ruang majlis dan ruang rumah kyai yaitu ruang kolaborasi eksternal, berbentuk usaha kerjasama resiprokal, maka fase lima ini ruang-ruang pesantren menjadi: 1) Ruang Masjid, 2) ruang majlis, 3) ruang madrasah, 4) ruang usaha internal, 5) ruang kolaborasi eksternal dan 6) ruang rumah kyai.

Keseluruhan ruang-ruang pesantren yaitu masjid, majlis, madrasah, ruang usaha internal, ruang kolaborasi eksternal dan ruang rumah kyai tersebut menciptakan komunitas. Komunitas tersebut terbentuk karena aktivitas yang ada pada ruang-ruang tersebut. Komunitas pada ruang masjid pada awalnya tidak terbedakan antara peserta suluk (yang belajar ilmu agama secara mendalam) dengan jamaah sholat, namun seiring terbentuknya majlis sebagai tempat khusus belajar agama, maka di masjid dapat terbedakan antara orang yang mengikuti kegiatan sholat saja dengan orang yang belajar lebih dalam tentang ilmu agama. Orang yang hanya mengikuti kegiatan sholat disebut sebagai komunitas jamaah masjid, sedangkan mereka yang aktif di majlis taklim dapat disebut sebagai jamaah masjid taklim. Kedua jamaah ini patut dibedakan, karena dilihat dari kedekatan dengan kyai kedua jamaah ini mempunyai tingkat kedekatan yang berbeda. Jamaah majlis taklim memiliki keeratan yang lebih dekat dengan kyai dinamdingkan dengan jamaah Masjid. Jamaah majlis taklim inilah yang sebenarnya disebut sebagai santri.

Terjadinya pemecahan dari majlis taklim ke ruang yang lebih formal, yaitu hadirnya madrasah sebagai ruang complementary majlis taklim, memunculkan santri formal di ruang madrasah. Madrasah bukan hanya melahirkan santri mondok tetapi juga santri kalong, yaitu peserta didik yang tidak tinggal di asrama tetapi tinggal di rumah masing-masing. kehadiran jamaah yang mondok baik sebagai santri madrasah maupun jamaah majlis taklim, menciptakan potensi pemberdayaan ekonomi internal. Pemberdayaan ekonomi internal yang paling sederhana adalah menghadirkan kelembagaan untuk memenuhi kebutuhan santri secara mandiri. Munculah lembaga ekonomi yang bersifat bisnis, contohnya adalah koperasi pesantren (kopontren). Koperasi Pesantren beranggotakan santri dan juga pengurus pondok. Untuk menyediakan barang-barang kebutuhan anggota, koperasi bekerjasama dengan fihak luar sebagai supplier:Koperasi pondok pesantren merupakan cikal bakal bisnis dan pembuka jalan bagi kolaborasi tradisi santri yang fokus pada pembelajaran agama dengan struktur ekonomi luar yang bersifat mencari keuntungan.

Koperasi telah menciptakan karakter non tradisi pesantren, yang pada akhirnya menjadi alasan kuat menjadikan alumni pondok pesantren untuk tidak harus selalu berprofesi sebagai juru dakwah atau profesi bidang-bidang keagamaan lainnya tetapi dapat juga menjadi wira usaha. Tercatat di Di Sidogiri, mereka yang pada saat menjadi santri adalah pengelola koperasi pesantren, setelah lulus mereka memilih profesi non juru dakwah. Interaksi mereka dengan suplier koperasi membuat jejaring baru di lingkungan pesantren. Demikian halnya dengan pengelolaan keuangan, perputaran jumlah uang yang tidak sedikit memaksa mereka untuk berurusan dengan perbankan untuk menyimpan dan menarik keuangan.

Dari pengalaman dan jejaring yang mereka miliki, mereka berkolaborasi dengan almamaternya untuk ikut membangun jaringan Bisnis. Transaksi antara pengalaman dan peluang dengan potensi pasar pesantren yang luas menciptakan pola kolaborasi saling menguntungkan. Perhitungan konpensasi bisnis mulai diterapkan pada sistem ini. komposisi pengelola (entrepreunership alumni) dengan pesantren dan kyai sebagai pemilik pasar dan brand dilakukan dengan asas proporsional. Pembentukan ruang-ruang bisnis adalah bentuk transformasi ekonomi pesantren yang cukup progresif, mengingat pesantren selama ini dikenal sebagai lembaga pendidikan tradisional yang orientasinya adalah menciptakan kader rohaniwan daripada mempersiapkan lulusannya menjadi entrepreuneur.

Sztompska (2010) mengemukakan bahwa pada prinsipnya setiap entitas atau institusi yang ada di muka bumi akan mengalami perubahan-perubahan. Perubahan-perubahan tersebut dapat diketahui bila dilakukan suatu analisa perbandingan masa tertentu dengan masa lainnya. Hal tersebut juga dapat dilihat pada lembaga pesantren. Simmel sebagaimana dikutip oleh Lechner (1991) membagi pendekatan konsep ruang sosial menjadi tiga kategori. Pertama; ruang sosial dikembangkan dari asumsi dasar interaksi non fisik dalam arti interaksi menggunakan simbol-simbol tertentu dalam dominasi kepentingan untuk mencapai tujuan. Kepentingan menjadi salah satu elemen penting yang berfungsi sebagai sekat yang membatasi ruang satu dengan lainnya. Meskipun dibatasi oleh sekat, interaksi dapat berlangsung karena adanya kesamaan unsur-unsur yang dipergunakan sebagai pengait untuk mengatakan kepentingan yang sama. Kedua; model interaksi tersebut merupakan bentuk interaksi "alternatif" dari bentuk normatifnya karena adanya perilaku konformitas atas sebuah situasi tertentu — yang terpaksa masyarakat harus meresponsnya ke dalam bentuk-bentuk konformitas. Ketiga; sebagaimana kelanjutan poin pertama dan kedua maka dimensi ruang membentuk pengelompokan berdasarkan pada atribut-atribut tertentu berskala horizontal maupun vertikal. (Lechner :1991)

Berbeda dengan pandangan Tonnies, transformasi ruangruang pesantren dari yang sebelumnya menggambarkan kesederhanaan (fase satu sampai fase tiga) kemudian memasuki fase yang lebih kompleks (fase empat dan fase lima) dimana unsur-unsur perkotaan yang diwujudkan dengan tumbuhnya ruang-ruang usaha dan kolaborasi, tidak serta merta pesantren berubah dari komunitas berkarakter Gemeinschaft yang kolektif, berubah menjadi komunitas berkarakter Gesellschaft yang individualistik. Pesantren justru mempertahankan ciriciri kolektivitas, homogenitas, berorientasi pada konformitas (kepentingan bersama) ketika memasuki kehidupan moderen.

Munculnya ruang usaha di pesantren dan juga ruang kolaborasi tidak sepenuhnya menunjukkan apa yang dikatakan oleh Henri Levebre ( dalam Stanley Aronowitz, :2008.) dengan teorinya yang disebut produksi ruang (production of space). Argumen 


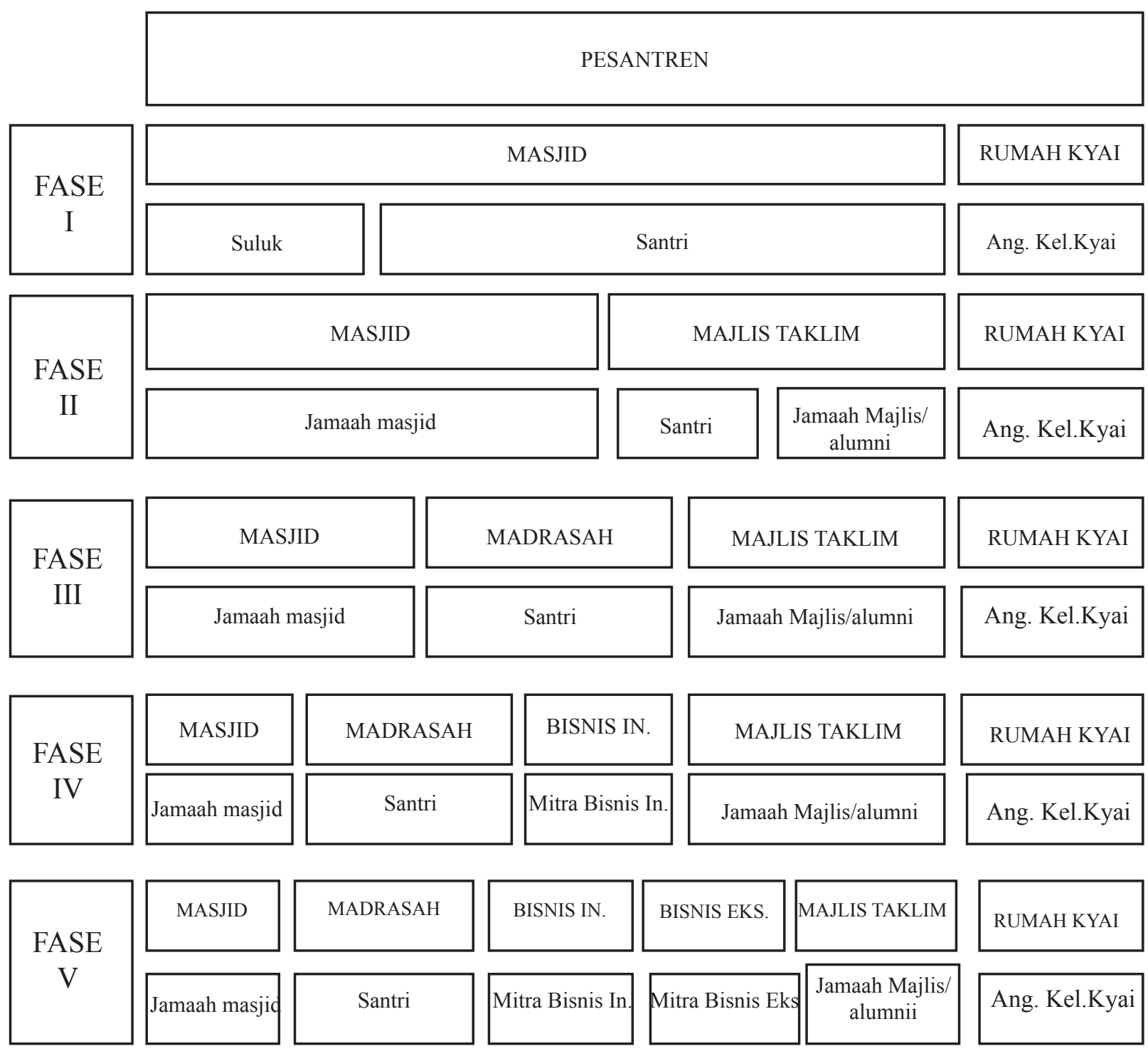

Gambar 2. Perkembangan Ruang Ekonomi dan Komunitas di Pesantren

Levebre mengenai produksi ruang lebih memfokuskan pada persoalan bagaimana praktek-praktek sosial diposisikan sebagai aktivitas produksi. Menurut Levebre produksi ruang menjadi kunci dari keberhasilan kapitalisme. Ruang ekonomi difahami sebagai perilaku manusia dalam mengorganisi ruang produksi melalui hubungan sosial yang berorientasi pada kepentingan kapital. Ruang- ruang dikonstruksikan dan diciptakan sebagai alat kontrol. Ruang yang dikonstruksikan dan diciptakan oleh menusia melalui hubungan sosial yang melahirkan sebuah pengetahuan merupakan upaya dari dominasi dan melanggengkan sebuah kekuasaan. Selanjutnya ruang ekonomi dalam konteks global membentuk ruang hampa yang diciptakan sebagai pusat produksi kapitalis. Ruangruang produksi yang berdimensi ekonomi di pesantren, secara faktual merupakan ruang untuk menciptakan kapital, tetapi kapital yang diperoleh tidak untuk kepentingan individu tetapi untuk kepentingan komunitas. Bahkan keberadaan ruangruang bisnis baru secara operasional mengurangi otoritas kyai. Kyai harus berbagi pada kelompok lainnya yang dianggap lebih memahami dari segi ilmunya.

Pandangan Karl Marx bahwa ruang ekonomi adalah ruang usaha untuk menggerakkan modal melalui proses produksi yang melibatkan tenaga kerja, uang, barang, maupun jasa. Menurutnya Ruang ekonomi menjadi kunci dari akumulasi kapital yang melahirkan kapitalisme. Dalam kapitalisme terdapat dua kelas di dalam masyarakat, kelas atas dan kelas bawah. Kelas atas, kaum kapitalis, merupakan kaum eksekutif yang menguasai produksi. Kelas bawah merupakan kelompok buruh yang cenderung mendapatkan perlakuan eksploitatif dari kaum kapitalis. (Duncan Foley and Gérard Duménil : 2008) Kapitalisme dalam marxisme memiliki tiga karakteristik utama. Pertama, semua komponen produksi memiliki harga jual. Mulai dari bahan mentah hingga jasa dari tenaga buruh, semuanya memiliki nilai yang dapat ditukarkan. Karakteristik kedua adalah dalam industri pemilik semua produksi hanyalah satu kelas saja, kaum kapitalis. Hal ini berkaitan dengan karakteristik ketiga yaitu kaum buruh yang berada dalam posisi ingin bertahan hidup di dunia yang terkuasai harus menjual jasa mereka kepada kaum kapitalis. Marxisme menyebutkan bahwa efek dari kapitalisme adalah makin melebarnya kesenjangan antara mereka yang kaya dan yang miskin (Hobden, Stephen \& Jones, Richard W: 2001) Pilihan pesantren pada kelembagaan koperasi merupakan sebuah pilihan menjembatani kebutuhan akan akumulasi modal untuk menggerakkan pesantren tetapi di satu sisi membangun kolektivitas sebagai ciri pesantren. Sekalipun secara faktual telah muncul nilai-nilai barang dalam raung pesantren, tetapi tidak serta merta nilai-nilai barang tersebut terakumulasi pada 
satu kelompok.

\section{Komunitas Ruang Ekonomi pesantren}

Dari sisi komunitas sesuai dengan fase perkembangan ruang -ruang yang dimilikinya, komunitas pesantren dapat dilihat pada gambar 2 .

1) Fase pertama Komunitas pesantren hanya terdiri dari Kyai dan anggota keluarganya beserta santri peserta suluk.

2) Fase dua komunitas pesantren terdiri dari Jamaah masjid, santri dan keluarga kyai

3) Fase tiga komunitas pesantren terdiri dari Jamaah masjid, santri, jamaah majlis dan keluarga kyai.

4) Fase Empat komunitas pesantren terdiri dari Jamaah masjid, santri, jamaah majlis, mitra bisnis internal dan keluarga kyai.

5) Fase Lima komunitas pesantren terdiri dari Jamaah masjid, santri, jamaah majlis, mitra bisnis internal, mitra bisnis eksternal dan keluarga kyai.

Komunitas di atas dibagi menjadi dua yaitu; komunitas internal yang tinggal di pondok pesantren dengan komunitas eksternal yang tinggal di luar pondok pesantren. Komunitas internal adalah santri dan anggota keluarga kyai, sedangkan yang eksternal adalah jamaah masjid, jamaah majlis taklim, mitra bisnis internal dan mitra bisnis eksternal.

Karakteristik komunitas pesantren dari fase satu sampai pada fase ke tiga merupakan komunitas yang memiliki tingkat kerekatan yang tinggi. Kerekatan ini disebabkan oleh adanya kesamaan latar belakang pendidikan, kesamaan guru dan kesamaan simbolsimbol keagamaan. Merujuk pada penjelasan Tonnies (1955), komunitas pesantren menyerupai konsep Gemeinschaft dan Gesellschaft. Gemeinshcaft

merujuk pada jenis komunitas yang berkarakter dimana setiap individu maupun aspek sosial yang ada pada komunitas tersebut berinteraksi secara vertikal dan horizontal, berjalan dengan stabil dalam waktu yang lama, adalah hasil dari adanya pertukaran ritual maupun simbol-simbol sebagaimana yang terjadi dalam interaksi sosial secara nyata yang dibangun faceto-face interaction. Inilah yang di sebut Tonnies komunitas (dalam pengertian) tradisional; dimana setiap individu membantu individu yang lain, setiap individu mengenal identitas atau informasi individu yang lain, dan ikatan yang terjalin antar-individu sangat kuat serta menjelma dalam berbagai wujud.

Komunitas pesantren sampaipada fase tiga inijuga mengingatkan kepada konsep Solidaritas mekanik yaitu suatu kelompok sosial yang didasar-kan pada kesadaran kolektif, kebersamaan, dan hukum yang berlaku bersifat menekan. Sebagaimana juga dalam konsep solidaritas mekanik, di pesantren terdapat totalitas kepercayaan dan sentiment-sentimen bersama yang sama. Individualitas tidak ditonjolkan karena kehidupan komunitas pesantren lebih berorientasi pada konformitas (kepentingan bersama). solidaritas komunitas pesantren terbentuk dengan tingkat homogenitas yang tinggi dalam kepercayaan, sentiment, dan kebersamaan mencapai kepentingan bersama.

Pada fase ke emapat dan kelima, Tumbuhnya ruang -ruang bisnis pesantren tidak serta merta melahirkan komunitas Gesselscahft dimana komunitas memiliki kepentingan dan komitmen yang berbeda-beda, tidak adanya ikatan antar- individu, tidak ada norma dan nilai-nilai yang menjadi pengikatnya, hubungan antar-individu sangat dangkal dan lebih bersifat instrument formal belaka. Hal-hal yang terjadi di pesantren justru sebaliknya. Dalam gesellschaft, komunitas tidak berkembang secara simultan dan tidak membesar; meski anggota komunitas yang ada di dalamnya secara kuantitas berjumlah besar, dan setiap individu akan bertemu denga individu lainnya setiap waktu namun hubungan yang terjalin hanyalah parsial dan sementara. Berbeda dengan komunitas pesantren tumbuhnya ruang-ruang ekonomi menimbulkan hubungan integral, justru menciptakan kepentingan bersama membuat keterikatannya dengan almamater serta mendekatkan antar individu di antara mereka.

\section{Perubahan Struktur, Peran dan Fungsi Pesantren}

Katabolisme yang terjadi pada ruang-ruang pesantren berdampak kepada struktur fungsi dan peran pesantren. kompleksitas ruangruang yang ada di dalam pesantren, menyebabkan rentang kendali kyai sebagai pemimpin pesantren menjadi sangat lebar. Sementara kompetensi Kyai untuk mengontrol aktivitas non pengajaran agama, seperti mengontrol koperasi dan usaha lain sangatlah terbatas. Sekalipun kehidupan komunitas pesantren lebih berorientasi pada konformitas, solidaritas, tingkat homogenitas yang tinggi dalam kepercayaan, sentimen, dan kebersamaan mencapai kepentingan bersama, namun tetap melahirkan kelompok elite baru di internal pesantren yang disebut dengan pengurus Pesantren. Kyai harus mau berbagi otoritas dengan elite baru yang muncul di lingkungan pesantren. Disinilah dapat memunculkan suatu ketergantungan yang berbeda yang disebabkan oleh modal.

Munculnya ruang-ruang bisnis di pesantren, pada satu sisi menguatkan kemandirian pesantren. Namun marwahnya, sebagai sebuah entitas pencari surplus usaha, mengharuskan adanya kalkulasi jelas melalui berbagai sistem pencatatan yang akuntabel. Untuk itu Pesantren harus memasukan sistem-sistem tata kelola keuangan yang mengadopsi sistem akuntansi publik. Disamping itu bisnis yang melibatkan alumni menciptakan perhitungan konpensasi bisnis berupa komposisi pengelola (entrepreneurship alumni) dengan pesantren dan kyai sebagai pemilik pasar dan brand dilakukan dengan asas proporsional. Sistem ini adalah model pendekatan kapitalisme modern. Dengan kata lain hadirnya aktivitas bisnis di pesantren, membutuhkan sekaligus menciptakan perangkat kapitalisme. Weber menyebutkan bahwa kapitalisme adalah upaya manusia untuk mendapatkan keuntungan. Kegiatan usaha yang dimaksud bukanlah sekedar perdagangan dan pertukaran barang saja. Menurutnya, kapitalisme harus mengandung aspek kunci, yakni adanya penghitungan pengeluaran dan pemasukan yang akuntabel, tenaga kerja yang bebas, adanya pengakuan hak milik pribadi termasuk keuntungan yang dinilmati secara pribadi,adanya pasar dan jejaring pasar yang tidak dibatasi oleh aturan-aturan irasional, adanya kelembagan hukum yang mengikat (Collin :1980), teknologi produksi skala besar bisa dihasilkan (Swedber :1992).

Dilihat dari kondisi empirik yang ada pesantren sekalipun mengedepankan solidaritas dan menekankan pada aspek keadilan, tetap merupakan sebuah sistem dengan dasar-dasar pengelolaan kapital yang bersifat material.

Kemandirian yang dicita-citakan oleh pesantren, karena telah menggunakan perangkat kapitalisme. bukanlah hal-hal yang berlawanan dengan prinsip-prinsip Islam. ${ }^{1}$ Maka no poin

1 Dalam Islam kegiatan sosial-ekonomi (muamalah) mempunyai cakupan luas dan fleksibel,. kehidupan bisnis dan transaksi harus berbasiskan nilai-nilai dan prinsip-prinsip Syariah yang bersumber dari Al Quran dan Hadits serta dilengkapi dengan Al Ijma dan Al Qiyas. Sistem perekonomian Islam, Sistem Ekonomi Islam mempunyai beberapa tujuan, yakni:(1). Kesejahteraan Ekonomi dalam kerangka norma moral Islam (QS. Al-Baqarah ayat $2 \& 168$, Al-Maidah ayat 
return bagi pesantren untuk terus memutar kapital yang dimilikinya dengan terus mengoptimalkan ruang-ruang produksi yang dimilikinya. Pesantren mempunyai infrastruktur untuk hal tersebut. Sekalipun sampai saat ini pesantren bertahan dengan prinsip keislaman, namun tetap pada ancaman konsekuensi : ketika terjadi pelemahan pada kontrol moral dari pengajaran agama, dan kharisma kyai yang dimilikinya, maka pesantren dapat menjadi mesin kapitalisme serakah sebagaimana umumnya.

\section{KESIMPULAN DAN SARAN}

Pesantren telah mengalami dinamika perubahan. Tekanan politik untuk melemahkan dirinya yang pernah dialami justru dalam jangka panjang menghasilkan vivalisme, bukan sekedar pada ruang dunia pendidikan tetapi menumbuhkan ruang-ruang ekonomi.

Ruang-ruang bisnis, yang tumbuh di lingkungan pesantren diawali dengan keinginan untuk bersikap mandiri, terutama dari campur tangan negara. Pesantren mampu menggunakan komunitas sebagai resultanta aktivitasnya menjadi lokus-lokus produksi yang mengakumulasi modal.

Munculnya ruang-ruang bisnis di pesantren, pada satu sisi menguatkan kemandirian pesantren. Namun marwahnya, sebagai sebuah entitas pencari surplus usaha, mengharuskan menciptakan perhitungan konpensasi bisnis dengan terus mengoptimalkan ruangruang produksi yang dimilikinya. Memang Akumulasi modal, tidak menunjukkan korelasi dengan upaya-upaya melanggengkan kekuasaan dan otoritas tunggal kyai ataupun akumulasi kapital pribadi kyai sebagai pimpinan tertinggi, sebagaimana kritik marxian terhadap kapitalisme. Justru proses produksi yang menghasilkan akumulasi modal menciptakan segmentasi kepemimpinan di lingkungan pesantren.

Pada tataran idealisme, Ruang usaha di pesantren masih bertahan secara ideal sebagai tempat berkumpulnya jamiah seluruh elemen pesantren, baik yang dipinggir atau yang di tengah sentrum pesantren dalam sebuah proses interaksi komunitas yang beridentitaskan Islam. Namun demikian sekalipun sampai saat ini pesantren bertahan dengan prinsip keislaman, namun tetap pada ancaman konsekuensi: ketika terjadi pelemahan pada kontrol moral dari pengajaran agama, dan kharisma kyai yang dimilikinya, maka pesantren dapat menjadi mesin kapitalisme serakah sebagaimana umumnya.

\section{DAFTAR PUSTAKA}

Halim A, et al. 2005. Manajemen Pesantren. Pustaka Pesantren (Kelompok Penerbit LKiS). Yogyakarta.

Abdurrahman mas'ud. 2004. Intelektual Pesantren: Perhelatan Agama dan Tradisi. LKIS, Yogyakarta.

Achmad Faozan. 2006.Pondok Pesantren dan Pemberdayaan Ekonomi. Ibda': Jurnal Studi Islam dan Budaya, Vol 4/1 pp. 88-102.

Azzahra Fatimah. Dharmawan AH, 2015. Pengaruh Livelihood Assets Terhadap Resiliensi Nafkah Rumah Tangga Petani pada Saat banjir di Desa Sukabakti Kecamatan Tambelang Kabupaten bekasi. Sodality

87-88, Al-Jumu'ah ayat 10); (2).Membentuk masyarakat dengan tatanan sosial yang solid, berdasarkan keadilan dan persaudaraan yang universal (Qs. Al-Hujuraat ayat 13 , Al-Maidah ayat 8 , Asy-Syu'araa ayat 183) (3).Mencapai distribusi pendapatan dan kekayaan yang adil dan merata (QS. Al-An'am ayat 165, AnNahl ayat 71, Az-Zukhruf ayat 32); (4).Menciptakan kebebasan individu dalam konteks kesejahteraan sosial (QS.Ar-Ra'du ayat 36, Luqman ayat 22).
Jurnal Sosiologi Pedesan. Vol 03, No.01 April 2015. Hal.5.

Departemen Agama. 1998. Sejarah Perkembangan Madrasah, Direktorat Jendral Pembinaan Kelembagaan Agama Islam.

Duncan Foley and Gérard Duménil. 2008. Marx’s analysis of capitalist production. The New Palgrave Dictionary of Economics.

Frank Lechner. 1991. Simmel on Social SpaceTheory, Culture \& Society (SAGE, London, Newburry Park and New Delhi) Vol 8 pp. 195-201.

Fukuyama, F. 1995. Trust: The Social Virtues and the Creation of Prosperity. Free Press. New York.

Denzin, N.K., Lincoln Y.S. 2000. Handbook of Qualitative Research. (Second Edition). Sage Pul. Inc. Thousand Oaks.

Hasanah, Uswatun. 2002. Manajemen Kelembagaan Wakaf (The Waqf Institutional Management), Research Paper Submitted at International Workshop on Empowering Muslim Society Economic Through Management of Productive.

Hobden, Stephen \& Jones, Richard W., 2001. Marxist Theories of International Relations, dalam Baylish, John \& Smith, Steve (eds), The Globalization of World Politics an Introduction to International Relations. Oxford University Press. New York.

I'laamus Saajid bi Ahkaamil Masajid karya az-Zarkasyi (hal.27)

Maksum. 1999. Madrasah Sejarah dan Perkembangannya. Logos Wacana Ilmu. Jakarta.

Muhammad Wasitho. 2010. Bisnis Syariah, Majalah Pengusaha Muslim, Edisi 2/Volume I/Februari 2010.

Putnam, Robert D. 2000. Bowling Alone: The Collapse and revival of American Community, New York: Simon and Schuster.

QS. Az-Zukhruf [43] ayat 32.

Randall Collins, Weber's Last Theory of Capitalism: A Systematization, American Sociological Review Vol. 456 (Dec., 1980), pp. 925-942.

Resume Focus Group Discussion, penulis dengan Malis Keluarga, Pengelola PP. Sidogiri dan Pengurus Kopontren PP.Sidogiri, Manajemen Koperasi UGT Sidogiri. Tanggal 18 Januari 2015.

Richard Swedberg, The Sociology of Economic Life. (edited with Mark Granovetter) Boulder, Co: Westview Press, 1992; 2nd and enlarged ed. 2001.

Soekanto Soerjono. 1982. Sosiologi Suatu Pengantar. Jakarta CV. Rajawali.

Stanley Aronowitz, The Ignored Philosopher and Social Theorist: On the Work of Henri Lefebvre. in: Situations, 2/1 pp. 133-155.

Sztompka. 2010. Sosiologi Perubahan Sosial. Prenada. Jakarta. Tonnies Ferdinand : Community and Association.1955. dalam Soekanto Soerjono, Sosiologi Suatu Pengantar, Jakarta CV. Rajawali.

Tuty Alawiyah.1999. Strategi Dakwah di Lingkungan Majelis Taklim. Mizan. Bandung.

Woodward Mark . R. Islam Jawa: kesalehan Normatif versus Kebatinan, Lkis, 1999. hal. 207.

Yoyok Rimbawan, "Pesantren Dan Ekonomi" (Kajian Pemberdayaan Ekonomi Pesantren Darul Falah Bendo Mungal Krian Sidoarjo Jawa Timur ), Confrence Proceedings. Annual International Confrence on Islamic Studies (AICIS) XII. Hal. 182.

Zamakhsyari Dhofier. 1983.Tradisi Pesantren Studi tentang Pandangan Hidup Kyai. LP3S. Jakarta. 